\title{
OPTIMASI RUTE LOKASI WISATA KOTA MALANG MENGGUNAKAN METODE ALGORITMA GENETIKA
}

\author{
Aditya Bagus Prakoso', Yuri Ariyanto ${ }^{2}$, Ariadi Retno Tri Hayati Ririd ${ }^{3}$ \\ Program Studi Teknik Informatika, Jurusan Teknologi Informasi, Politeknik Negeri Malang \\ ${ }^{1}$ adityabagusprakoso3194@gmail.com, ${ }^{2}$ yuri.bjn@gmail.com, ${ }^{3}$ faniri4education@ gmail.com
}

\begin{abstract}
Abstrak
Wisata adalah kegiatan perjalanan yang dilakukan oleh seseorang atau sekelompok orang yang mengunjungi tempat tertentu untuk beberapa tujuan seperti rekreasi maupun mempelajari keunikan daya tarik wisata yang dikunjungi. Permasalahan yang sering muncul adalah minimnya informasi mengenai jalur menuju tempat wisata, tingkat kepadatan jalur yang akan dilewati dan volume jalur tersebut dikarenakan waktu mereka yang terbatas.

Pencarian rute terpendek perjalanan wisata Kota Malang menggunakan algoritma genetika dapat dimanfaatkan pada permasalah tersebut, algoritma genetika merupakan salah satu model soft computing yang sering digunakan dalam menyelesaikan permasalahan optimasi dengan menggunakan konsep evolusi biologis dan dihasilkan output berupa kombinasi jalur rute perjalanan.

Sistem ini dapat digunakan untuk membantu wisatawan domestik maupun manca negara dalam mengenal Kota Malang untuk solusi dalam pencarian rute wisata di Kota Malang.
\end{abstract}

Kata kunci : Optimasi, Rute terpendek, Kota Malang, Algoritma Genetika

\section{Pendahuluan}

Wisata adalah kegiatan perjalanan yang dilakukan oleh seseorang atau sekelompok orang yang mengunjungi tempat tertentu untuk beberapa tujuan seperti rekreasi maupun mempelajari keunikan daya tarik wisata yang dikunjungi. Permasalahan yang sering muncul adalah minimnya informasi mengenai jalur menuju tempat wisata, tingkat kepadatan jalur yang akan dilewati dan volume jalur tersebut dikarenakan waktu mereka yang terbatas, oleh sebab itu pencarian rute terpendek menjadi hal yang penting.

Pencarian rute terpendek adalah bagaimana menentukan jalur yang paling optimal, jalur dengan rute terpendek dengan biaya terkecil, dalam penerapannya bermanfaat untuk mengetahui jalur terpendek, meningkatkan efektivitas pemberian informasi perjalanan, kebutuhan untuk memberikan beberapa jalur alternatif bagi pengguna jalan maupun berkendara. Maka diperlukan suatu metode untuk mendapatkan solusi yang optimal dari masalah tersebut.

Pencarian rute terpendek perjalanan wisata kota Malang menggunakan algoritma genetika dapat dimanfaatkan pada permasalah tersebut, karena algoritma genetika merupakan salah satu model soft computing yang sering digunakan dalam menyelesaikan permasalahan optimasi, dengan menggunakan konsep evolusi biologis maka dihasilkan suatu output berupa kombinasi jalur rute perjalanan. Terdapat tiga parameter penting dalam algoritma genetika yang harus didefinisikan yaitu ukuran populasi, probabilitas pindah silang, dan probabilitas mutasi. Penerapkan algoritma genetika pada permasalahan ini dibuatlah perangkat lunak. Pada perangkat lunak yang dibuat, diinputkan beberapa kombinasi lokasi tujuan wisata, kemudian dilakukan pengujian perangkat lunak dengan parameter-parameter algoritma genetika yang bervariasi dan akan diketahui kromosom terbaik. Maka diperlukan sistem "Pencarian Rute Optimum Lokasi Wisata di Kota Malang Menggunakan Metode Algoritma Genetika Berbais Web" yang diharapkan dapat memudahkan wisatawan dalam pencarian rute wisata yang optimal.

\section{Traveling Salesman Problem (TSP)}

Travelling Salesman Problem (TSP) merupakan salah satu permasalahan optimasi klasik yang sulit untuk dipecahkan secara konvensional yang dikenal denga persoalan Non Polinomial karena terdapat ruang pencarian dari sekumpulan permutasi sejumlah kota. Untuk menyelesaikan masalah TSP banyak metode optimasi yang dapat digunakan yaitu Hill Climbing Method, Ant Colony System, Dynamic Programming, Algoritma Greedy, Algoritma Brute Force dan Algoritma Genetika. Permasalahan utama dari TSP adalah bagaimana seorang salesman dapat mengatur rute perjalananannya untuk mengunjungi sejumlah kota yang diketahui jarak satu kota dengan kota lainnya sehingga jarak yang ditempuh merupakan jarak minimum dimana salesmen hanya dapat mengunjungi kota tersebut tepat satu kali. 
Penyelesaian TSP ialah bagaimana memperoleh total jarak yang minimum sehingga mendapatkan jalur terpendek. TSP dapat diselesaikan secara eksak akan tetapi harus melakukan perhitungan terhadap semua kemungkinan rute yang dapat diperoleh, kemudian memilih salah satu rute yang terpendek (Puspitorini, 2008). Jika terdapat sejumlah $\mathrm{n}$ kota yang harus dikunjungi, maka terdapat $\mathrm{n}$ ! kombinasi kota yang akan dibandingkan jarak masing-masing kota tersebut. Sehingga akan membutuhkan waktu komputasi yang cukup lama apabila jumlah kota yang harus dikunjungi semakin banyak. Gambaran sederhana dari pengertian TSP adalah sebagai berikut:

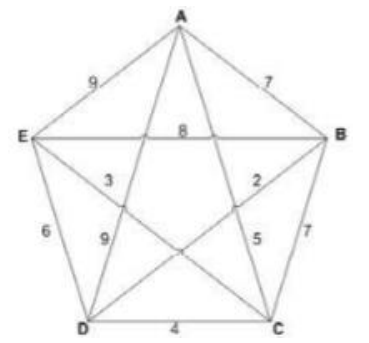

Gambar 2.1 Posisi kota-kota yang akan dilewati (Sumber: Annies,et al. 2002)

\section{Teori Graf}

Graf merupakan merupakan suatu cabang ilmu yang memiliki banyak terapan. Banyak sekali struktur yang dapat direpresentasikan dengan graf, dan banyak masalah yang bisa diselesaikan dengan bantuan graf. Seringkali graf digunakan untuk merepresentasikan suatu jaringan. Misalkan jaringan jalan raya dimodelkan graf dengan kota sebagai simpul (vertex/node) dan jalan yang menghubungkan setiap kotanya sebagai sisi (edge) yang bobotnya (weight) adalah panjang dari jalan tersebut.

Misalkan simpul merepresentasikan kota, sisi merepresentasikan perjalanan yang memungkinkan, dan bobot dari setiap sisi adalah biaya yang dikeluarkan dalam perjalanan yang memungkinkan, dan bobot dari setiap sisi adalah jarak yang ditempuh dalam perjalanan tersebut. Graf G didefinisikan sebagai pasangan himpunan (V, E). ditulis dengan notasi $\mathrm{G}=(\mathrm{V}, \mathrm{E})$, yang dalam hal ini $\mathrm{V}$ adalah himpunan tidak kosong dari simpulsimpul (vertices atau node) dan E adalah himpunan sisi (edges atau arcs) yang menghubungkan sepasang simpul. V tidak boleh kosong, sedangkan E boleh kosong. (Ristono dan Puryani, 2011).

\section{Lintasan Terpendek}

Persoalan mencari lintasan terpendek didalam graf merupakan salah satu persoalan optimasi. Graf yang digunakan dalam pencarian lintasan terpendek adalah graf berbobot (weighted graph), yaitu graf yang setiap sisinya diberikan suatu nilai atau bobot. Bobot pada sisi graf dapat menyatakan jarak antar kota, waktu pengiriman pesan, ongkos pembangunan, dan sebagainya. Asumsi yang digunakan di sini adalah bahwa semua bobot bernilai positif.

Lintasan terpendek adalah lintasan minimum yang diperlukan untuk mencapai suatu tempat dari tempat lain. Lintasan minimum yang dimaksud dapat dicari dengan menggunakan graf. Graf yang digunakan adalah graf yang berbobot yaitu graf yang setiap sisinya diberikan suatu nilai atau bobot.

\section{Tri Bina Cita Kota Malang}

Dalam salah satu Sidang Paripurna Gotong Royong Kotapraja Malang pada tahun 1962 ditetapkan Kota Malang sebagai : Kota Pendidikan; Kota Industri; dan Kota Pariwisata. Ketiga pokok tersebut menjadi cita-cita masyarakat Kota Malang yang harus dibina, oleh karena itu kemudian disebut TRI BINA CITA KOTA MALANG.

\section{Google Maps}

Google Maps merupakan layanan pemetaan berbasis web service yang disediakan oleh Google secara gratis. Google juga menyediakan layanan Google Maps API yang merupakan pengembangan teknologi dari google yang digunakan untuk menanamkan Google Map di suatu aplikasi yang tidak dibuat oleh Google. Google Maps API adalah suatu library yang berbentuk JavaScript yang memiliki sifat server-side, yaitu peta yang tersimpan pada server Google dapat dimanfaatkan oleh pengguna berguna untuk memodifikasi peta yang ada di Google Maps sesuai kebutuhan.

\section{Algoritma Genetika}

Algoritma genetika merupakan salah satu model soft computing dan cabang dari algoritma evolusi, metode yang digunakan untuk memecahkan suatu pencarian nilai dalam sebuah masalah optimasi (Mitsuo\& Runwei, 2000). Soft Computing adalah suatu model pendekatan untuk melakukan komputasi dengan meniru akal manusia dan memiliki kemampuan untuk menalar dan belajar pada lingkungan yang penuh dengan ketidak pastian (Jang, dkk, 1997).

Dalam algoritma genetika terdapat tiga parameter penting yang harus didefinisikan yaitu ukuran populasi, probabilitas pindah silang, dan probabilitas mutasi. Ketiga parameter ini harus didefinisikan secara hati-hati agar tidak terjadi lokal optimum dimana individu-individu dalam populasi pada suatu solusi tidak dapat memukan hasil paling optimum (Suyanto, 2005).

Kromosom merupakan representasi dari solusi. Operator genetika yang terdiri dari crossover dan mutation dapat dilakukan kedua-duanya atau hanya salah satu saja yang selanjutnya operator evolusi dilakukan melalui proses seleksi kromosom dari parent (generasi induk) dan offspring (generasi 
turunan) untuk membentuk generasi baru yang diharapkan akan lebih baik dalam memperkirakan solusi optimum, proses iterasi kemudian berlanjut sesuai dengan jumlah generasi yang telah ditetapkan.

\section{Perancangan Sistem}

Pada pembuatan sistem ini digunakan metode algoritma genetika untuk melakukan optimasi rute, flowchart umum perancangan sistem optimasi yang dibuat bisa dilihat pada Gambar 8.1 dan berikut flowchart dari proses optimasi:

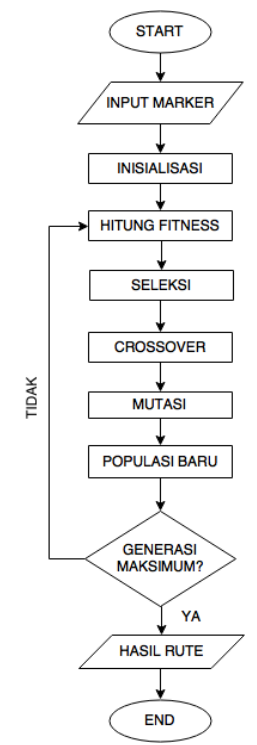

Gambar 8.1 Flowchart Perancangan Sistem

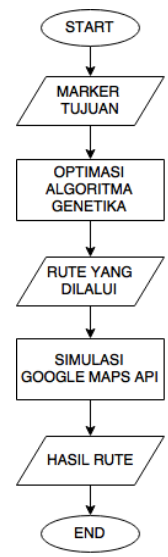

Gambar 8.2 Flowchart Proses Optimasi

Sistem ini dibuat untuk membantu wisatawan domestik maupun mancanegara yang berkunjung di kota Malang untuk berwisata maupun mengeksplorasi lokasi-lokasi wisata yang ada di kota Malang. Sistem ini menggunakan metode algoritma genetika sebagai penyelesaian dari optimasi rute lokasi wisata.

\section{Siklus aplikasi}

Gambaran siklus jalannya aplikasi pengguna masukkan lokasi awal dan lokasi tujuan menggunakan perantara web, kemudian aplikasi melakukan perhitungan data input marker untuk mencari rute optimal menggunakan media internet untuk mengambil data yang diolah JavaScript dimana data tersebut sebelumnya di generate oleh $P H P$ dari database $M y S Q L$.

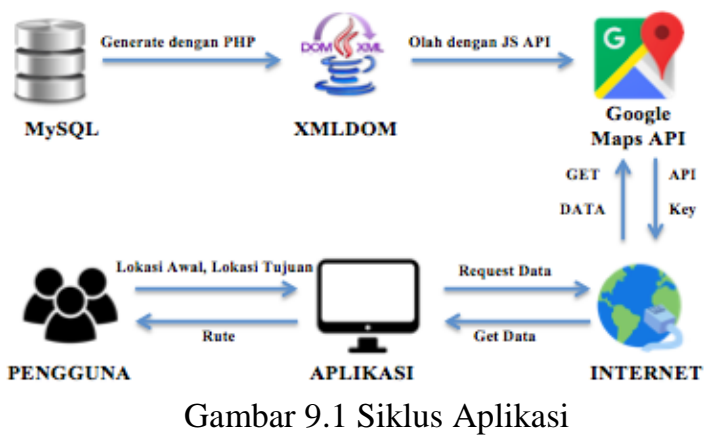

\section{Implementasi Database}

Berikut ini adalah tabel yang di implementasikan pada database MySQL dengan bantuan interface PHPMYADMIN.

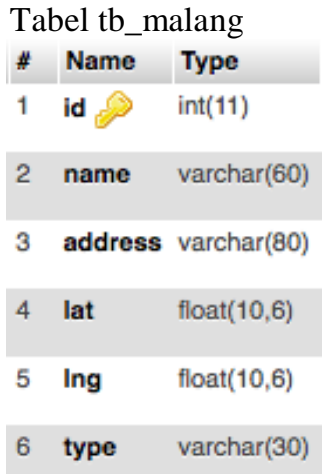

Gambar 10.1 Tabel tb_malang

a. Data tb_malang

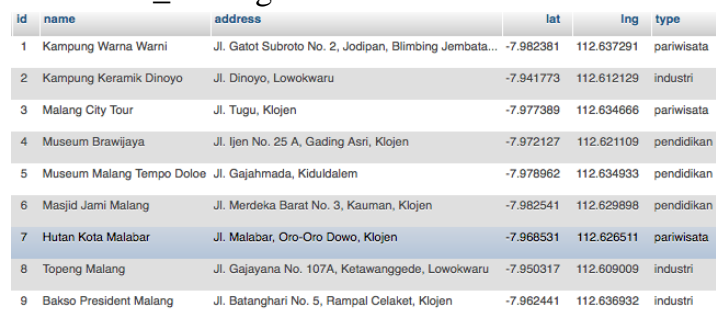

Gambar 10.2 Data tb_malang

\section{Pengujian Hasil}

Pengujian hasil dilakukan dengan cara pengguna melakukan pencarian rute wisata dari lokasi awal ke tujuan kemudian di lakukan pengecekan apakah rute wisata yang dihasilkan sudah merupakan rute optimal. 
a. Percobaan Pertama

Pada percobaan pertama penguji menggunakan 3 marker lokasi tujuan.

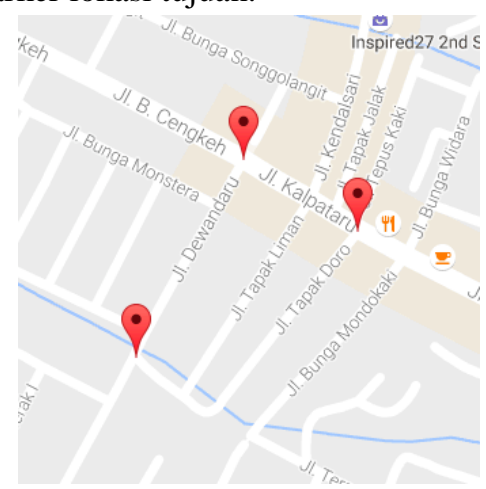

\section{Konfigurasi}

Travel Mode Avoid Highways

Populasi

Mutasi

Crossover

Elitism

Max Generations

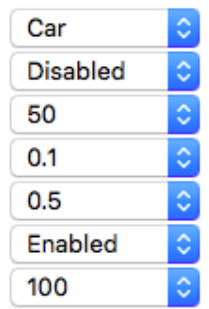

Debug Info

Destinations Count:3

\section{Start Clear}

Gambar 11.1 Percobaan Pertama

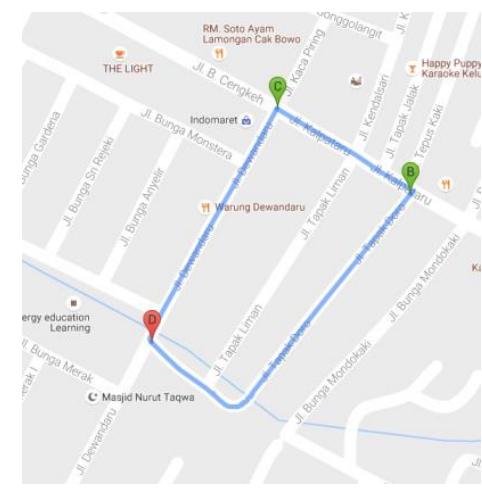

\section{Konfigurasi}

Travel Mode

Avoid Highways

Populasi

Mutasi

Crossover

Elitism

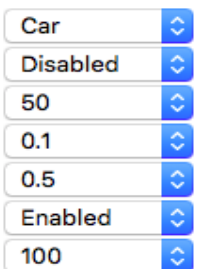

Max Generations

Debug Info

Destinations Count:3

Generations: $\quad 100$

Best Time 2.63 Mins

Start Clear

Gambar 11.2 Hasil Percobaan Pertama b. Percobaan Kedua

Pada percobaan kedua penguji menggunakan marker lokasi tujuan yang sama dengan berbeda parameter.

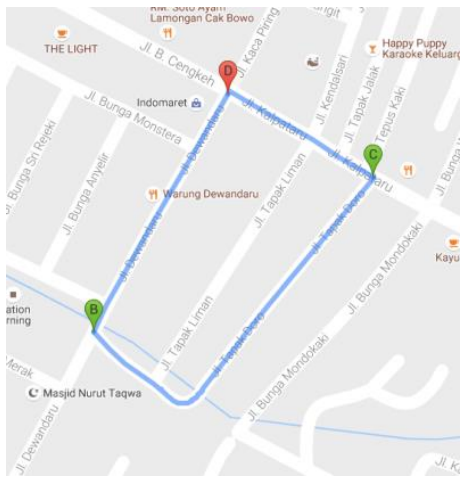

\begin{tabular}{l|ll} 
Konfigurasi & & \\
Travel Mode & Car & $\hat{v}$ \\
\hline Avoid Highways & Disabled & $\hat{v}$ \\
\hline Populasi & 50 & $\hat{v}$ \\
\hline Mutasi & 0.1 & $\hat{v}$ \\
\hline Crossover & 0.5 & $\hat{v}$ \\
\hline Elitism & Disabled & $\hat{v}$ \\
\hline Max Generations & 100 & $\hat{v}$ \\
\hline
\end{tabular}

Debug Info

Destinations Count: 3

Generations: $\quad 100$

Best Time 2.10 Mins

\section{Start Clear}

Gambar 11.3 Hasil Percobaan Kedua

Dari kedua percobaan diatas menghasilkan hasil yang berbeda, ketika parameter Elitism digunakan dan tidak digunakan. tanpa menggunakan elitism, nilai fitness individu terbaik cenderung naik pada tiap generasi tetapi nilai pada tiap generasi selalu naik turun, sedangkan jumlah generasi yang digunakan juga banyak, jika menggunakan elitisme nilai fitness individu terbaik selalu terjaga dan nilainya cenderung naik terus, jumlah generasi yang dipakai untuk mendapat individu terbaik yang diinginkan juga lebih sedikit.

\section{Kesimpulan dan Saran}

Berdasarkan pembahasan yang telah dilakukan pada bab 1 hingga bab 6, maka dapat disimpulkan bahwa :

1. Sistem ini digunakan untuk membantu wisatawan domestic maupun manca negara dalam mengenal Kota Malang untuk solusi dalam pencarian rute wisata di Kota Malang.

2. Sistem yang dibuat berhasil menentukan rute optimal dari lokasi awal ke tujuan. 
Saran yang diberikan untuk pengembangan sistem ini ke depannya adalah penelitian ini dapat dilanjutkan dengan menggunakan metode optimasi yang lain sebagai perbandingan dalam mendapatkan hasil rute optimal wisata dari lokasi awal ke tujuan.

\section{Daftar Pustaka:}

Anhar,ST., 2010. Panduan Menguasai PHP \& MYSQL Secara Otodidak.Jakarta Selatan:Mediakita

Goldberg, D., 1989, Genetic algorithm in search, optimization and machine learning, AddisonWesley.

Gossett, Eric., 2009. Discrete Mathematics With Proof.Canada:John Wiley \& Son

Hidayatno A, Dkk. 2011 "Penerapan Algoritma Genetika Pada Perencanaan Lintasan Kendaraan". Jurnal, Jurusan Teknik Elektro, Fakultas Teknik, Universitas Diponegoro.

Kartika Gunadi, Yulia, 2014. "PERENCANAAN RUTE PERJALANAN DI JAWA TIMUR DENGAN DUKUNGAN GIS MENGGUNAKAN METODE ALGORITMA GENETIKA ":Universitas Kristen Petra Fakultas Teknologi Industri, Jurusan Teknik Informatika

Michael Purvis,Jeffrey Sambells,Cameron Turner, 2006. Beginning Google Maps Applications with PHP and Ajax. New York:Apress

Mulyanto, Eddy., Sutojo, T. \& Suhartono, Dr.Vincent.2011. Kecerdasan Buatan, Yogyakarta : ANDI Yogyakarta dan UDINUS Semarang.

Permatasari,Riski, 2014. APLIKASI INFORMASI RUTE WISATA KOTA DI KOTA MALANG PADA PERANGKAT ANDROID:Politeknik Negeri Malang, Jurusan Jaringan Telekomunikasi Digital: Laporan akhir tidak diterbitkan

Pranata,Antony, 1997. Panduan Pemrograman Javascript. Yogyakarta:Andi

Siswanto, 2010, Kecerdasan Tiruan, Edisi Pertama, Cetakan Kedua, Yogyakarta : Graha Ilmu.

Solichin, Achmad., 2010. MySQL 5 Dari Pemula Hingga Mahir.Jakarta:Achmatim.net

ST, Suyanto.2014.Artificial Intelligence. Jakarta : INFORMATIKA.

Supardi, Yanuar,Ir., 2007. Pemrograman Java dan MySQL.Jakarta:Elex Media Komputindo

Weber, C. Edward, J. Neal ford, and Christopher R. Weber.1996. Developing with Delphi: object-Oriented Techniques. Prentice Hall. 